\title{
When the Physician Says You Have to Get the Shot, BUt MOMmY Says No: The CaSes OF TAIGE MUELlER AND DANIEl HAUSER, AND HOW THE STATE MAY ForCe PARENTS TO ACCEPT UNWANTED MEdiCAL TREATMENT FOR THEIR CHILDREN
}

\section{Zach Williams ${ }^{*}$}

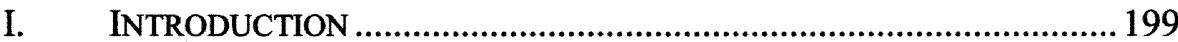

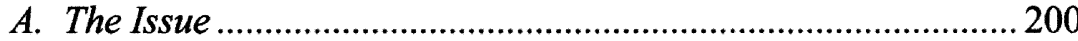

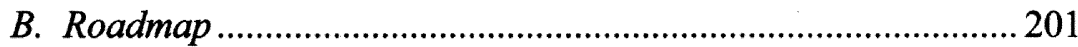

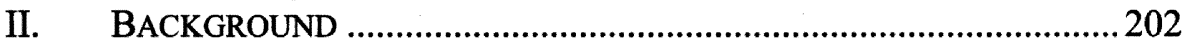

A. The Case of Taige Mueller............................................................ 202

B. The Incident Involving Daniel Hauser .......................................203

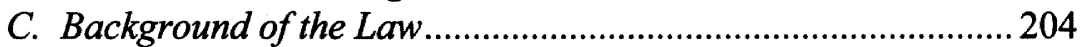

1. The Interest of the Parent ......................................................204

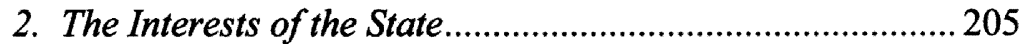

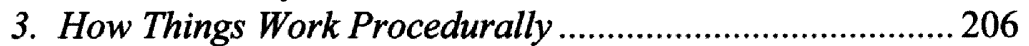

D. The Cause for Concern According to Parents..........................207

E. The Cause for Concern According to the State..........................207

F. The Cause for Concern According to the Physician...................208

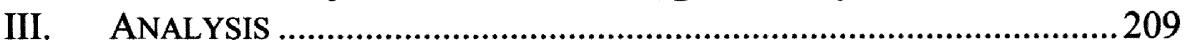

A. Examining the Mueller Civil Suit ............................................209

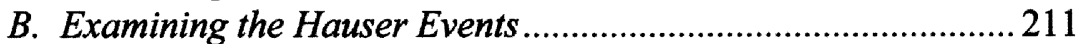

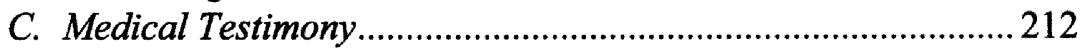

D. Procedural Complications....................................................... 215

E. Did Neglect Mandate State Intervention?..................................217

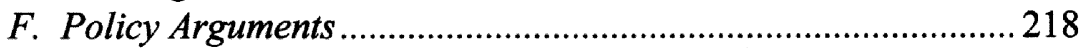

1. Protecting the Child ............................................................. 219

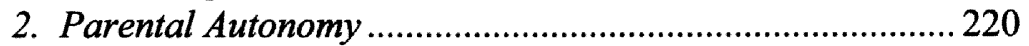

3. The Physician's Role.............................................................. 221

4. State Actors Charged With Deciding What to Do in Difficult Situations ................................................................. 222

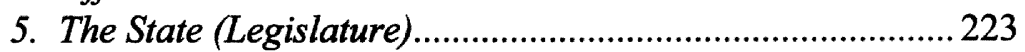

G. Possible Solution to a Complicated Problem ............................ 223

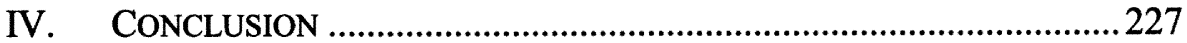

\section{INTRODUCTION}

At first glance, it seems difficult to imagine a scenario in which a

* J.D. Candidate, 2011, Indiana University School of Law - Indianapolis; B.A., 2004, Indiana University. 
competent parent would refuse medical care for their child. However, what if the proposed treatment for the child is dangerous, or the parent feels that another course of treatment would be safer for the child, or what if the parent simply does not trust the medicine that is being recommended? If a parent refuses medical treatment for his or her child, the state could intervene and take that child away, forcing the refused treatment on the child despite any fears or apprehensions from the child's parent.'

Imagine that your infant child is ill, and you bring her to the hospital. The doctor wants to do a spinal tap, a possibly risky procedure for an infant. You argue with the physician and strongly feel the procedure is unnecessary. Instead of the physician following your wishes, he instead contacts the police and child services departments. The authorities refuse to defer to your opinion on how to care for your infant daughter, and instead take custody of her. The state then approves the spinal tap procedure on your infant, and she remains in their custody for the rest of the day. As the ordeal ends, you discover that your daughter was fine all along.

This hypothetical may invoke some complicated emotions for many parents, but it is important to recognize the other parties involved in this situation: the incompetent child, the concerned physician, and the state itself, which is charged with protecting the child's welfare. ${ }^{2}$ Thus, it is possible that the physicians and state authorities in the above scenario believed they were acting in the best interest of the child, and the parent's wishes were ignored as a result.

The above hypothetical is a catalyst for debating parents' autonomy in caring for their child, contrasted with the state's interest in protecting the child when it believes the child's safety may be at risk. However, this is not a hypothetical, as this scenario actually occurred. ${ }^{3}$

\section{A. The Issue}

The central issue of this controversy comes from a struggle between parents choosing what medical care they believe is best for their child and the state disagreeing with that choice. The Fourteenth Amendment of the United States Constitution has long protected the rights of citizens. ${ }^{4}$ From this protection, the Supreme Court of the United States has inferred that a competent person has a protected liberty interest in choosing to refuse unwanted medical care. ${ }^{5}$ In the common law, children in our society are deemed to be incompetent, and unable to make decisions regarding their

1. See Custody of a Minor, 393 N.E.2d 836, 843-44 (Mass. 1979); People ex rel. Wallace v. Labrenz, 104 N.E.2d 769, 773 (Ill. 1952).

2. See Prince v. Massachusetts, 321 U.S. 158, 165 (1944).

3. See Mueller v. Auker, 576 F.3d 979 (9th Cir. 2009).

4. U.S. CONST. amend. XIV.

5. See Cruzan v. Director, Missouri Dept. of Health, 497 U.S. 261, 278 (1990). 
medical care. ${ }^{6}$ Instead, the decision to accept or refuse medical treatment is left to the child's parents. ${ }^{7}$ This Note discusses the difficulties that arise when the decision to treat is taken away from the parents, because the state believes the child's welfare may be at risk. ${ }^{8}$ Specifically, this Note looks at what happens when the decision centers on a parent's desire to refuse medical care for their child because the parent believes the care to be unnecessary, dangerous, or simply unwanted, as demonstrated by the cases of Taige Mueller, ${ }^{9}$ and Daniel Hauser. ${ }^{10}$

\section{B. Roadmap}

This Note identifies the factual background of the case of Taige Mueller ${ }^{11}$ and compares it with the situation involving Daniel Hauser, who along with his parents, disagreed with the prescribed treatment to battle the cancer that had infiltrated his body, but was forced to follow the orders of his physicians through intervention from the state. ${ }^{12}$ The case involving Taige Mueller was heard in June of 2010, with a jury finding that the seizure of Taige from her mother's custody did not amount to a violation of any of her parents' Constitutional rights. ${ }^{13}$ The controversy surrounding Daniel Hauser is next contrasted with Taige Mueller's experience, to examine the inherent difficulties faced by parents, physicians, and the state in determining who should decide the course of treatment for a sick child.

This Note also briefly examines the current state of the law in regards to the state's authority and duty to a sick child whose parent decides against or disagrees with prescribed medical treatment for her child. It will then analyze the current state of the law in regards to the Mueller and Hauser scenarios, while examining the roles that each interested party (parent, physician, and state) played in the process. ${ }^{14}$ By highlighting the difficulties faced in balancing the parents' right to care for their child with the state's

6. Melinda T. Derish \& Kathleen V. Heuvel, Mature Minors Should Have the Right to Refuse Life-Sustaining Medical Treatment, 28 J.L. MED. \& ETHICS 109, 110 (2000).

7. See id. (arguing that the current state of the law denying mature children the right to refuse medical care should be changed).

8. See Custody of a Minor, 393 N.E.2d 836, 843-44 (Mass. 1979); People ex rel. Wallace v. Labrenz, 104 N.E.2d 769, 773 (IIl. 1952).

9. Mueller v. Auker, 576 F.3d 979 (9th Cir. 2009).

10. Aaron Cooper \& Chris Davis, Judge Orders Chemotherapy for 13-Year-Old Cancer Patient, CNN, (May 26, 2009), http://www.cnn.com/2009/US/05/26/minnesota.forced .chemo/index.html.

11. Mueller, 576 F.3d at 982-87 (9th Cir. 2009).

12. See Cooper \& Davis, supra note 10.

13. Press Release, The Center for Individual Rights, The Latest News from CIR: Jury Finds no Liability in Mueller Case (June 30, 2010), available at http://www.cirusa.org/updates/index.html.

14. The role of the child in the decision-making process is outside of the scope of this Note, which instead chooses to focus on the parties who are practically involved in deciding what kind of medical care the child should receive. 
interest in protecting the welfare of the child, ${ }^{15}$ this Note attempts to flesh out the inherent problems in the current approach to this issue. Finally, this Note suggests a procedure by which the interests of the parties could be balanced fairly, while maintaining the child's safety.

\section{BACKGROUND}

\section{A. The Case of Taige Mueller}

In 2002, Corissa Mueller's five-week-old infant daughter, Taige, became ill and began running a fever. ${ }^{16}$ Corissa consulted with Taige's family physician over the phone, and the physician suggested possible causes for Taige's fever. ${ }^{17}$ The family physician discussed the probable procedures that Taige would undergo if Corissa chose to take her to the hospital. ${ }^{18}$ One of the potential examinations involved a spinal tap procedure to check for meningitis. ${ }^{19}$ A spinal tap procedure consists of a needle being placed in between two vertebrae in order to remove cerebrospinal fluid for testing. ${ }^{20}$ Corissa discussed the treatment protocols with her husband, Eric Mueller. ${ }^{21}$ After receiving reassurance from Taige's family physician, Taige's parents believed they would have the ability to withhold consent should the hospital physician recommend the spinal tap procedure. ${ }^{22}$

Corissa took Taige to the hospital while Eric Mueller, Taige's father, remained at home to care for the couple's other child. ${ }^{23}$ The hospital physician examined Taige and recommended various examinations including a spinal tap and administration of prophylactic antibiotics, and also warned that there was a five percent chance that Taige had meningitis. ${ }^{24}$ Corissa disagreed with the doctor's assessment, based on her own research about Taige's risk for meningitis. ${ }^{25}$ After Taige's temperature began to drop, Corissa refused to consent to the spinal tap procedure. ${ }^{26}$ The hospital physician in charge of Taige's care contacted

15. See Prince v. Massachusetts, 321 U.S. 158, 166 (1944) ("[T] he custody, care and nurture of the child reside first in the parents, whose primary function and freedom include preparation for obligations the State can neither supply nor hinder.").

16. Mueller, 576 F.3d at $982-83$.

17. Id.

18. Id. at 983 .

19. Id.

20. Lumbar Puncture (Spinal Tap), Mayo Clinic, (Jan. 23, 2010) http://www.mayoclinic.com/health/lumbar-puncture/MY00982.

21. Mueller, 576 F.3d at 983.

22. Id.

23. Id.

24. Id.

25. Id.

26. Id. at 983-84. 
Child Protective Services ("CPS"), and a detective from the local police department was dispatched along with CPS workers. ${ }^{27}$ Based on the physician's insistence that time was limited (i.e., three hours), and Corissa's refusal to consent to the spinal tap, the detective declared Taige to be in imminent danger and removed her from her mother's custody. ${ }^{28}$ Corissa was restrained and confined to a small room while "screaming and yelling" the entire time. ${ }^{29}$ Hospital physicians obtained the necessary consent from CPS, who had already assumed custody of Taige, and then conducted the spinal tap procedure against the wishes of Taige's mother. ${ }^{30}$ Corissa was prohibited from informing her husband over the phone, and she was not reunited with her daughter until a day later. ${ }^{31}$ The results of the spinal tap procedure were negative. ${ }^{32}$

\section{B. The Incident Involving Daniel Hauser}

In 2009, thirteen-year-old Daniel Hauser and his mother fled their home after a judge ordered that Daniel comply with his physician's recommendation to begin chemotherapy to treat Daniel's cancerous tumors. ${ }^{33}$ Daniel had been diagnosed with Hodgkin's Lymphoma in January of 2009..$^{34}$ Initially, Daniel's parents consented to the treatment recommended by Daniel's treating physician, and Daniel was given an initial round of chemotherapy. ${ }^{35}$ Daniel's parents allegedly became fearful of the side effects of chemotherapy after the initial treatment, and decided to pursue an alternative treatment plan. ${ }^{36}$

After Daniel failed to show up for further treatments, his physician became concerned and left a voice message on the Hauser's phone threatening to call the authorities if Daniel did not resume his chemotherapy. ${ }^{37}$ After receiving no response from the Hausers, Daniel's physician contacted the authorities. ${ }^{38}$ Court documents reveal that the

27. Id. at 984 .

28. Id.

29. Id. at 985.

30. Id. at 986 .

31. Id. at $983-86$.

32. Amy Sorrel, Idaho Emergency Physician Sued for Overriding Parent's Decision, AM. MED. NEwS, (Apr. 9, 2007), http://www.ama-assn.org/amednews/2007/04/09/gvsb0409. htm.

33. See Cooper \& Davis, supra note 10.

34. Mother, Son Missing in Forced Chemotherapy Case, CNN, (May 20, 2009), http://www.cnn.com/2009/US/05/19/minnesota.forced.chemo/index.html [hereinafter Mother, Son Missing].

35. Id.

36. Id.

37. Chris Welch, Father Appeals to His Wife to Return With Their Cancer-Stricken Son, CNN, (May 21, 2009), http://www.cnn.com/2009/US/05/21/minnesota.forced.chemo /index.html.

38. Id. 
judge had ordered Daniel to undergo an examination, and that Daniel had actually undergone the procedure; however, Daniel and his mother disappeared the day before they were scheduled to appear. ${ }^{39}$ As a result, the court removed Daniel from his parent's custody and authorized police officers to apprehend the missing child. ${ }^{40}$ Daniel's father pled with the mother-son duo to return home so that the dispute could be settled "as a family." 41

Daniel and his mother eventually returned and consented to treatment following a hearing in which the judge ordered treatment at the risk of Daniel being removed from his parent's custody ${ }^{42}$ Fortunately, as of his fourteenth birthday, Daniel was free of cancer. ${ }^{43}$

\section{Background of the Law}

There are two competing interests immediately evident when reviewing the Mueller and Hauser situations: the parent and the state. When these two interests collide on the issue of selecting medical care for a sick child, then scenarios like those described above are entirely possible.

\section{The Interest of the Parent}

Supreme Court precedent has established that the custody and care of children resides with their parents. ${ }^{44}$ Parents are given leeway to care for their children without interference from the state. ${ }^{45}$ In addition, this right is constitutionally protected: "Parents and children have a well-elaborated constitutional right to live together without governmental interference. That right is an essential liberty interest protected by the Fourteenth Amendment's guarantee that parents and children will not be separated by the state without due process of law except in an

39. Order to Apprehend and Detain, In re Hauser, No. JV-09-068, at 5 (Minn. Dist. Ct. May 19, 2009), available at http://www.mncourts.gov/Documents/0/Public/Other/Hauser/ Order_to_Apprehend_and_Detain.pdf (ordering police to apprehend and detain Daniel Hauser).

40. Id.

41. See Welch, supra note 37.

42. Order, In re Hauser, No. JV-09-068, at 7 (Minn. Dist. Ct. May 26, 2009), available at http://www.mncourts.gov/Documents/0/Public/Other/Hauser/Order5.27.09.pdf (forcing Daniel's parents to follow the prescribed treatment of Daniel's physicians, less he be removed from their custody).

43. Scott Wasserman, Daniel Hauser Turns 14, Is Cancer Free, Fox 9 NEws KSMPTV, (Mar. 28, 2010), http://www.myfoxtwincities.com/dpp/news/Daniel-Hauser-Turns-14,Is-Cnacer-Free-mar-28-2010.

44. See Prince v. Massachusetts, 321 U.S. 158, 166 (1944).

45. See Santosky v. Kramer, 455 U.S. 745 (1982). 
emergency." 46 Thus, the law assumes that the parent of a sick child will act in that child's best interest. ${ }^{47}$ A competent person has a constitutionally protected interest in refusing medical treatment, ${ }^{48}$ but a child is not automatically considered competent in the eyes of the law. ${ }^{49}$ Therefore, the decision of whether or not a child should receive medical treatment traditionally falls to the child's parent. ${ }^{50}$

Returning to the case of Taige Mueller, the presumption that parents will act in their child's best interest can be readily applied. Taige's mother had conducted her own research on the spinal tap procedure and believed that the risks of the spinal tap procedure outweighed its benefits. ${ }^{51}$ Ultimately, Corissa Mueller believed the risk of Taige having meningitis to be less than one percent and, as a result, saw no need to subject her daughter to the procedure ${ }^{.52}$ Taige's mother came to a rationally sound decision based on her own interpretations of the spinal tap procedure and decided to forgo the treatment in what she considered her child's best interest ${ }^{53}$

Viewing only the principles concerning a parent's interest in caring for his or her child, it would seem that Corissa Mueller's decision would be protected and require no further interference from the state. Seemingly, these principles would also protect the decision by Daniel Hauser's parents. However, this analysis fails to consider the state's competing interest.

\section{The Interests of the State}

"[T]he State has a long-standing interest in protecting the welfare of children living within its borders." in caring for his or her child without interference from the state, the state may interfere if a child's well-being is at risk. ${ }^{55}$ The state may intervene in extraordinary circumstances (e.g., when the child's life may be in danger) by temporarily removing the child from the parent's custody. ${ }^{56}$ The state's concern arises from its interests in: (1) the preservation of the welfare

46. See Wallis v. Spencer, 202 F.3d 1126, 1136 (9th Cir. 2000).

47. See generally Thomas Jacobs, 2 CHILDREN \& THE LAW: RigHTS AND OBLIGATIONS $\S 10: 3$.

48. See Cruzan v. Director, Missouri Dept. of Health, 497 U.S. 261 (1990).

49. See Derish \& Heuvel, supra note 6 , at 110.

50. See Bartal v. Brower, 993 P.2d 629 (Kan. 1999); Belcher v. Charleston Area Med. Ctr., 422 S.E.2d 827 (W. Va. 1992).

51. Mueller v. Auker, 576 F.3d 979, 983 (9th Cir. 2009).

52. Id.

53. Id. at 984.

54. Custody of a Minor, 379 N.E.2d 1053, 1066 (Mass. 1978).

55. Wisconsin v. Yoder, 406 U.S. 205, 233-34 (1972) (holding, "[T] he power of the parent ... may be subject to limitation ... if it appears that parental decisions will jeopardize the health or safety of the child.").

56. Bendiburg v. Dempsey, 909 F.2d 463, 467 (11th Cir. 1990). 
of the child ${ }^{57}$ and (2) the doctrine of parens patriae, ${ }^{58}$ or the authority to protect children from negligent parenting. ${ }^{59}$ These two interests may overlap, as the well-being of the child may directly coincide with whether his parents are deemed negligent in their choice of medical care. Additionally, a parent's decision could affect the well-being of the child in such a way that both of the state's interests are adversely affected.

There is a presumption that parents will act in the best interest of their children. ${ }^{60}$ However, this presumption may be rebutted when a parent refuses medical care for her child that the state believes is necessary to secure that child's well-being. ${ }^{61}$ Seemingly, this would mean that in order for the state to step in against a parent's wishes, the parent would be deemed unfit to care for her child, at least in that particular instance.

\section{How Things Work Procedurally}

When the state takes a child into custody, the parents generally have a right to a pre-deprivation hearing before custody of the child is taken away. ${ }^{62}$ Nevertheless:

[W] hen the State has "reasonable cause to believe that the child is in imminent danger of serious bodily injury and ... the scope of the intrusion is reasonably necessary to avert that specific injury," a State has the authority without prior judicial authorization to compel a minor child to undergo specific medical treatment over parental objections. ${ }^{63}$

In Mueller, the officer believed that Taige was in imminent danger because of the risk of meningitis and a limited time in which to act. ${ }^{64}$ For Daniel Hauser, his physicians believed that there was a high likelihood of curing him with treatment, but that failure to treat would likely

57. Custody of a Minor, 379 N.E.2d at 1066.

58. Parens patriae literally means "parent of his or her country" and refers to the role of the State as guardian of persons under legal disabilities, such as juveniles or incompetent persons. BLACK'S LAW DICTIONARY, 1144 (8th ed. 2004).

59. John E.B. Myers, Neglect of Children's Health: Too Many Irons in the Fire, 8 J.L. FAM. STUD. 317, 318 (2006).

60. See, e.g., Troxel v. Granville, 530 U.S. 57 (2000).

61. Parham v. J.R., 442 U.S. 584, 604 (1979).

62. See Mueller v. Auker, 576 F.3d 979, 995 (9th Cir. 2009); Stanley v. Illinois, 405 U.S. 645 (1972).

63. Mueller, 576 F.3d at 995 (quoting Wallis v. Spencer, 202 F.3d 1126, 1138 (9th Cir. 2000)).

64. Mueller, 576 F.3d at $984-985$. 
be fatal. ${ }^{65}$

Simply from reading the factual patterns of both Taige Mueller's and Daniel Hauser's respective cases, it is evident that the imminence and seriousness of the medical condition directly affects the procedural outcome from the parent's perspective. This notion is supported by the fact that Taige Mueller's parents did not receive any sort of predeprivation hearing regarding the custody of their daughter, seemingly because of the imminence and seriousness of the medical condition. ${ }^{66}$ Generally, parents are entitled to a hearing before their children can be taken away from them. ${ }^{67}$ The exception to this rule comes into effect when the state believes that the child is in imminent danger, and the interference is necessary to avoid injury. ${ }^{68}$

\section{The Cause for Concern According to Parents}

Based on the above principles, in certain situations parents may have little choice when it comes to their child's medical care, especially when the parents disagree with the child's physician, and the physician feels strongly enough to involve the state. This idea is compounded by the general principle that the state will leave the child's well-being in the parent's control, unless the parent's actions put the well-being of the child at risk. $^{69}$ This could mean that simply disagreeing with a physician who feels strongly enough about the child's care may be enough to rebut the presumption that parents are fit to care for their children. This very real potential for losing the ability to choose medical care for their child would erode the autonomy that is granted to them in caring for their child. ${ }^{70}$

\section{E. The Cause for Concern According to the State}

There are also difficulties from the state's perspective. These difficulties arise because "neither the State nor private actors, concerned for the medical needs of a child, can willfully disregard the right of parents to generally make decisions concerning the treatment to be given to their children."71 For example, the state will not order a blood transfusion if the

65. Judge Rules Family Can't Refuse Chemo For Boy, MSNBC (May 19, 2009), http://www.msnbc.msn.com/id/30763438/ns/health-kids_and_parenting/ [hereinafter Judge Rules Family Can't Refuse Chemo].

66. Mueller, 576 F.3d at $979,982$.

67. See Stanley, 405 U.S. 645.

68. Wallis, 202 F.3d at 1138

69. Wisconsin v. Yoder, 406 U.S. 205, 233-34 (1972) ("the power of the parent ... may be subject to limitation ... if it appears that parental decisions will jeopardize the health or safety of the child").

70. See cases cited supra notes $44-46$ and accompanying text.

71. Bendiburg v. Dempsey, 909 F.2d 463, 470 (11th Cir. 1990). 
child's medical condition is not life-threatening, and the parents object to the procedure. ${ }^{72}$ In addition, the state is unlikely to remove the child from the parent's custody and let the physician make the decision alone where the treatment is considered highly dangerous and the likelihood of success is not particularly certain. ${ }^{73}$ This further serves to indicate the importance of the state carefully weighing each individual case based on numerous factors, including the child's condition, the time under which to treat, and the parent's wishes. ${ }^{74}$ The problem with this approach is that there may be other instances like that in Mueller, where a physician may believe immediate action is required, and the state is pressured into making a quick decision. In these cases, it will be difficult for the state to balance the parents' interest in caring for their child ${ }^{75}$ and the state's interests in protecting the child's well-being. ${ }^{76}$

\section{F. The Cause for Concern According to the Physician}

Finally, there is a third player involved in scenarios like Mueller and Daniel Hauser's situation - the physician. Physicians are charged with caring for their patients. ${ }^{77}$ Therefore, when a physician feels strongly enough about a treatment option, he or she may disregard the wishes of a parent by involving the state, in order to secure what is believed to be the safest outcome for the child. This was seen in Mueller. ${ }^{78}$ The physician refused to concede to Corissa Mueller's wishes, and instead decided to involve the police and CPS. ${ }^{79}$ The physician stated that if he followed Corrissa Mueller's wishes with all his patients, five out of every hundred would die, and that would be unacceptable. ${ }^{80}$ It should be noted that the physician's assessment of the risk was called in to question in a lawsuit filed by the Muellers. ${ }^{81}$ In these situations, physicians may further complicate the issue if they do not consider the parents' right to care for their child without inter-

72. See, e.g., In re E.G., 549 N.E.2d 322 (Ill. 1989).

73. See, e.g., Newmark v. Williams, 588 A.2d 1108 (Del. 1991) (deciding to not order child with cancer to undergo radical form of treatment with a success rate of only forty percent).

74. See Mueller ex rel. Mueller v. Auker, No. CV-04-399-S-BLW, 2007 WL 627620, *14 (D. Idaho Feb. 26, 2007) (discussing what the state actor's analysis should include "the desires of the parents, their fitness, the risks of treatment compared with the risks of foregoing treatment, how soon the harm will occur, whether there is time to contact a judge, and any other factors given the circumstances.").

75. See Prince v. Massachusetts, 321 U.S. 158, 166 (1944).

76. See Custody of a Minor, 379 N.E.2d 1053, 1066 (Mass. 1978).

77. See generally The Hippocratic Oath: Modern Version, NOVA, http://www. pbs.org/wgbh/nova/doctors/oath_modern.html (last visited, Oct. 15, 2010).

78. Mueller v. Auker, 576 F.3d 979 (9th Cir. 2009).

79. Id.

80. Id. at 984.

81. Mueller ex rel. Mueller v. Auker, No. CV-04-399-S-BLW, 2007 WL 627620, *25

(D. Idaho Feb. 26, 2007). 
ference from the state. ${ }^{82}$

Ultimately, the state is charged with settling these disputes between physicians and parents. In Mueller, the physician and the state ordered a procedure that was unnecessary in hindsight, and one that Taige's mother expressly forbade the physician from performing. ${ }^{83}$ In Daniel Hauser's case, treatment was prescribed that he and his parents did not agree with, and Daniel was eventually forced by the court to accept that treatment. ${ }^{84}$ In both situations, the wishes of the parents were pushed aside in favor of the state's interest in protecting the child's well-being. The underlying question is whether these two scenarios could have been handled better.

\section{ANALYSIS}

These two instances provide a backdrop for analyzing the positive and negative aspects that the state must confront when a parent refuses medical care that a doctor feels is necessary to protect the child's life. This Note describes how one result turned out the "right" way, and the other ended the "wrong" way.

\section{A. Examining the Mueller Civil Suit}

Taige Mueller's role in the issue of forced medical care is useful for analyzing how the law applies when the state decides to intervene. More importantly, Taige's case may also provide a window into how the judicial system views these scenarios.

After their daughter was taken from them and given the spinal tap procedure, Taige's parents brought a civil suit against multiple parties involved in Taige's treatment and the eventual spinal tap procedure. ${ }^{85}$ The suit included Taige's physician, the detective that removed Taige from her mother's care, and the state social worker who ultimately consented to the procedure after custody of Taige was taken away. ${ }^{86}$ The Muellers were aided in their suit by a Washington D.C. based civil rights group. ${ }^{87}$ The trial was set for June of 2010 , and was decided by a

82. See Santosky v. Kramer, 455 U.S. 745 (1982).

83. Sorrel, supra note 32.

84. Order, In re Hauser, No. JV-09-068 (Minn. Dist. Ct. May 26, 2009), available at http://www.mncourts.gov/Documents/0/Public/Other/Hauser/Order5.27.09.pdf (order by the court forcing Daniel's parents to follow the prescribed treatment of Daniel's physicians, less he be removed from their custody).

85. See Mueller ex rel. Mueller, 2007 WL 627620, at *15-26 (discussing the individual defendants' roles in what transpired during the time when Taige was taken from her parents).

86. $I d$.

87. See Mueller v Auker: Parents' Right to Make Medical Decisions at Stake in Lawsuit, THE CENTER FOR INDIVIDUAL RIGHTS, http://www.cir-usa.org/cases/mueller_v_idaho. html (last updated May 20, 2010). 
jury in favor of the defendants. ${ }^{88}$ Without a judicial opinion to evaluate, it is impossible to know exactly how the case played out in front of a jury, however, the events leading up the trial give some window into how courts may view similar situations.

The main issues in the suit focused on both the substantive and procedural due process rights of Taige's parents, as well as whether those rights were violated when their daughter was given the spinal tap procedure against their wishes. ${ }^{89}$ Before the jury trial occurred, a district court ruled on whether these issues would survive summary judgment. ${ }^{90}$

The district court initially found that the detective violated the Muellers' procedural due process rights by failing to provide Taige's parents with pre- and post-deprivation notice before and after taking Taige into custody. ${ }^{91}$ The court also found that the state officials "violated the Muellers' rights by (1) failing to give post-deprivation notice to Eric Mueller, (2) communicating too broad a consent to treatment of Taige Mueller, and (3) holding Taige too long after the imminent danger had abated." $"$ The court retained the issue of whether or not Taige was actually in "imminent danger" for trial, along with issues of whether Taige's physician committed conspiracy when he exaggerated Taige's condition to the detective in order to have Taige removed from her mother's custody. ${ }^{93}$

The court's initial rulings suggested that it recognized a serious problem in Taige's case. By finding that both the detective and the state officials violated the Muellers' constitutional rights, the court was openly condemning the act of a physician calling in the authorities because of a disagreement over a medical course of action between mother and physician.

Nevertheless, two important issues prevented a resounding success for the Muellers in the early stages of their case. The first issue involved qualified immunity. ${ }^{94}$ The district court initially held that the state officials and the detective were entitled to qualified immunity on all claims except the detective's pre- and post-deprivation notice claims, and the officials' post-deprivation claim. ${ }^{95}$ The second issue involved an appeal by the detective to the 9th Circuit Court of Ap-

88. Press Release, The Center for Individual Rights, supra note 13.

89. See Mueller ex rel. Mueller, 2007 WL 627620, at *9-16.

90. Id. at *26-27.

91. Id. at *26.

92. Id.

93. Id.

94. See generally Scheuer v. Rhodes, 416 U.S. 232 (1974) (explaining the judicially created doctrine of qualified immunity used to protect officers of the executive branch from liability on the basis that officials must be afforded some protection or they will never act).

95. See Mueller ex rel. Mueller, 2007 WL 627620, at *26. 
peals. ${ }^{96}$ The court of appeals subsequently overruled the lower court's summary judgment against the detective, finding that he was entitled to qualified immunity, and that the doctrine was created specifically for cases like Taige's. ${ }^{97}$ Soon after, the state filed a motion to reconsider the district court's summary judgment for Eric Mueller's notice claim. ${ }^{98}$ The district court agreed with the state and reversed the summary judgment in favor of the Muellers' notice claim against the state. ${ }^{99}$

Thus, the interpretation by the courts before the jury trial occurred is difficult to gauge. On one hand, the district court maintained there were genuine issues of fact regarding whether Taige was in imminent danger, ${ }^{100}$ meaning that a jury could have found that the Mueller's procedural due process rights were violated when Taige was removed from their care. On the other hand, qualified immunity may prevent the state from being liable. Both the district court and the court of appeals seemed to recognize that the Muellers have been wronged. Ultimately, this case was decided by a jury in favor of the defendants, and not by a judge. ${ }^{101}$

While dicta in the circuit court's opinion suggest that what happened to the Muellers is "required by law based upon the need to allow government officials to make reasonable decisions,"102 a decision to override constitutional protections needs a legitimate reason, especially when it involves taking custody of a loving parent's child. Protecting officers of the state from repercussions stemming from their duties may not be a good enough rationale. Yet, the end result suggests that this may be a sufficient outcome, at least in the eyes of a jury.

\section{B. Examining the Hauser Events}

Daniel Hauser's treatment decision was ultimately resolved after a judge ordered Daniel to undergo chemotherapy. ${ }^{103}$ The events involving Daniel Hauser were different from that of Taige Mueller because of the effect the chosen medical care would have on each child. Daniel's physicians all agreed that he was unlikely to survive without chemotherapy, and that the prescribed treatment provided "a good chance of recov-

96. Mueller v. Auker, 576 F.3d 979 (9th Cir. 2009).

97. Id. at 1000-1001. 2009).

98. Mueller v. Auker, No. CV-04-399-S-BLW, 2009 WL 3806280 (D. Idaho Nov. 9,

99. Id. at *3.

100. See Mueller ex rel. Mueller, 2007 WL 627620 , at *26.

101. Press Release, The Center for Individual Rights, supra note 13.

102. Mueller, 576 F.3d at 1000.

103. Order, In re Hauser, No. JV-09-068, at 7 (Minn. Dist. Ct. May 26, 2009), available at http://www.mncourts.gov/Documents/0/Public/Other/Hauser/Order5.27.09.pdf. 
ery." 104 This immediately creates a large discrepancy, since the odds in Taige's case were only five percent that she might have meningitis. ${ }^{105}$ To properly fulfill its duty of parens patriae, the state must step in when the child's life is at risk, disregarding Daniel's and his parents' wishes. Seemingly, a child who faces certain death with treatment, and a high likelihood of survival with treatment, would demand state intervention.

\section{Medical Testimony}

Daniel's parents believed that an alternative treatment may have been more appropriate, and they actively sought holistic medicine after physicians administered Daniel's first dose of chemotherapy. ${ }^{106}$ Thus, there were two competing rationales behind Daniel's treatment: Daniel's parents' belief that holistic and alternative treatments were the best approach weighed against Daniel's physicians' belief that chemotherapy was the necessary treatment to save Daniel's life.

Daniel and his parents were given the opportunity to participate in a court hearing during which Daniel's physicians testified about the seriousness of Daniel's condition. ${ }^{107}$ At least one court has held that if medical evidence shows that prompt chemotherapy treatment is required, it would likely nullify any contrary evidence from a parent. ${ }^{108}$

This approach seems sound in situations like Daniel Hauser's, because it gives the court the opportunity to weigh both approaches and choose the safest option for children like Daniel. The court sided with Daniel's physicians because of the weight our society lends to medical advice. Daniel's parents were not physicians, and the state defers more to sound and tested evidence when comparing strictly medical evidence and testimony.

While Daniel's parents' opinion of proper treatment is important to their interest in caring for their child as they see fit, it does not necessarily follow that their opinion will conform to the best medical advice. Daniel's parents could have brought in a different medical expert their hearing. In fact, this would have been preferable, as it would have given the court an opportunity to see both sides of the medical evidence. If all of the relevant interests are taken out of the analysis, and

104. Id. at 5.

105. Mueller, 576 F.3d at 983.

106. See Cooper \& Davis, supra note 10.

107. See Findings of Fact, Conclusions of Law, and Order, In re Hauser, No. JV-09068, 2009 WL 1421504 (Minn. Dist. Ct. May 14, 2009) (speculating Daniel would be unlikely to survive without treatment and estimating a success rate of treatment between eighty-five and ninety-five percent) (page numbers unavailable).

108. See In re D.G., 970 So. 2d 486, 490 (Fla. Dist. Ct. App. 2007). 
these scenarios are viewed in a vacuum, it seems straightforward that the most reliable medical evidence could be used to make the decision.

If one only compares medical evidence in these two instances, there is a stark contrast between the small risk Taige Mueller had of actually having meningitis and the low chance of survival for Daniel Hauser. A small risk calls into question whether the child is actually in danger. The district court in Mueller stated that when "there is a close association between the risks of treatment and the risks of foregoing treatment . . . it is now the grim duty of the parents to make the call."109 On the other hand, when the discrepancy is much larger and the child's life is clearly at risk, the state should be able to override the parent's decision. ${ }^{110}$

This reasoning suggests a couple of important points to consider. First, it shows that wide discrepancy in risk in these two instances still yielded the same result in both: forced medical treatment contrary to the parent's wishes. Considering only the medical testimony from these two scenarios suggests that the court gives great weight to the physician's opinion. This may highlight more difficulties in scenarios like Taige Mueller's case, since the Muellers alleged in the suit that Taige's doctor might have exaggerated the danger in order to have Taige taken away from her mother. ${ }^{111}$

Another important point regarding medical testimony arises when parents have their own opinions or based on research. It is likely that in these scenarios, the parents' opinions or research will be largely discounted by the state. Corissa Mueller testified that she conducted her own research regarding the likelihood of her daughter having meningitis, and her opinion was that the odds were less than one percent. ${ }^{112}$ In addition, Corissa Mueller tried to explain to the detective that the risk of treatment outweighed the risks of illness, explaining that her own research indicated that the spinal tap "could cause an infection from the needle puncturing the spine. That you can cause meningitis itself from that procedure. That it can cause paralysis, can cause brain damage or severe headaches."113 This information ultimately was tossed aside in favor of Taige's physician's opinion.

109. Mueller ex rel. Mueller v. Auker, No. CV-04-399-S-BLW, 2007 WL 627620, *9 (D. Idaho Feb. 26, 2007); see also Tenenbaum v. Williams, 193 F.3d 581, 594 (2nd Cir. 1999) (stating that possibility of harm to a minor child is not enough for the State to take a child into custody).

110. See Custody of a Minor, 379 N.E.2d 1053 (Mass. 1978) (compelling child to undergo chemotherapy against parents' objections, because treatment had minimal side effects and would likely save child from dying).

111. See Mueller ex rel. Mueller, 2007 WL 627620 , at *25.

112. Mueller v. Auker, 576 F.3d 979, 983-84 (9th Cir. 2009).

113. Mueller ex rel. Mueller, 2007 WL 627620 , at *4 (referencing Corissa Mueller's deposition testimony). 
Similarly, Daniel Hauser's parents had their own opinions regarding his treatment and were under the impression that his treatment could be secured through holistic forms, because his family belonged to the Nemenhah Band religion. ${ }^{114}$ The leader of the religion believed that Daniel was entitled to his own choice in the matter. ${ }^{115}$ In this respect, Daniel's events differed from that of Taige Mueller. Daniel's parents' concerns rested somewhat on religious ideals, whereas Taige's mother based her opinion on research relating to spinal taps.

When viewing only the medical testimony of the respective parties in Daniel's case, without regard for any other interests, it seems logical to defer to trained medical professionals. While the court in the Daniel Hauser case came to the correct result, it must be noted that there are serious complications to chemotherapy treatment that both Daniel and his parents feared. ${ }^{116}$ In addition to the possible complications, there is also a potential fear that physicians may exaggerate their diagnosis in order to see that their opinion is followed.

These two instances indicate that any opinion a parent may have regarding the medical certainty of proposed treatment will be superseded by the physician's opinion. This can occur regardless of whether the discrepancy is a four percent difference (Corissa Mueller believed her daughter had a one percent chance of having meningitis and the physician believed that risk to be five percent) ${ }^{117}$ or whatever the odds Daniel's parents believed their alternative treatments had of curing his cancer. Nevertheless, the state's interest in protecting the well-being of Taige Mueller rested on only a five percent chance of the child being sick. The state's interest in protecting the well-being of Daniel Hauser was based on a high chance of his survival. Compared together, these two results suggest that any chance of a child being sick may be enough to outweigh the parent's wishes. However, there is case law that suggests when the risk from treatment is high enough, the court will defer

114. Dean Johnson, Nemenhah Band: No Chemo, Alternative Health J. (May 15, 2009), http://www.alternativehealthjournal.com/article/nemenhah_band_no_chemo/2811; see also About Us, NEMENHAH BAND, http://www.nemenhah.org/internal/about_us.html (discussing the basic history and mission of the Nemenhah Band of "natural healers") (last visited Jan. 3, 2011).

115. Id. ("The issue is Danny's right to decide how he wants to live his life .... What if they make him take chemotherapy and he dies from that? The band will mourn with the family if that's the case, but we'll rejoice that Danny had the opportunity to test the law of the land.").

116. Childhood Hodgkin Lymphoma Treatment, NAT'L CANCER INST., http://www.meb.uni-bonn.de/cancer.gov/CDR0000257999.html (detailing known risks such as problems with development of sexual organs, fertility problems, thyroid, heart, and long problems, increased risk of developing a secondary cancer, and bone growth problems).

117. Mueller v. Auker, 576 F.3d 979, 983-84 (9th Cir. 2009). 
to the parent's wishes. ${ }^{118}$

\section{Procedural Complications}

Perhaps the most glaring criticism of the way the Taige Mueller's case was handled is that her parents were never given the opportunity to be heard in a formal hearing. This procedural issue occurred chiefly because of the insistence by Taige's physician that there simply was no time. ${ }^{119}$ However, in Daniel's case, both his parents and his physician were given the opportunity to testify in front of a judge. ${ }^{120}$ Because of this, any interest that Taige's parents may have had in the care of their child was immediately overruled when the state became convinced that Taige needed the spinal tap procedure. This creates a concern that the state's interest in the preservation of Taige's well-being was based solely on the opinion of one physician.

Taige's parents were not afforded the opportunity to have their side of the story heard; rather, a single physician determined the care of their child. It is possible that if given the opportunity, Taige's parents could have found at least one physician who would have respected their decision. This is especially true since Taige's family physician had consulted with Corissa over the phone and advised her how to handle withholding consent from the spinal tap procedure. ${ }^{121}$

Generally, when the state takes a child into custody, parents have a right to a pre-deprivation hearing before they lose the custody of their child. ${ }^{122}$ In Taige's case, this presumption was rebutted because the child was thought to be in imminent danger. ${ }^{123}$ The problem with this line of reasoning is that Taige only had a five percent chance of being in imminent danger. ${ }^{124}$ According to the Ninth Circuit Court of Appeals, when the state believes that a child is in imminent danger, the state may compel treatment. ${ }^{125}$ Imminent danger should not be defined as a five percent risk of being sick. The reasoning behind the state's circumvention of Taige's parents' rights at the time was, thus, incorrect.

118. See Newmark v. Williams, 588 A.2d 1108 (Del. 1991) (deciding that court would not order child with cancer to undergo radical form of treatment with a success rate of only 40\%); but see Custody of a Minor, 393 N.E.2d 836 (Mass. 1979).

119. Mueller, 576 F.3d at 984.

120. See Mother, Son Missing, supra note 34.

121. Mueller, 576 F.3d at 983-84.

122. See id. at 995; Stanley v. Illinois, 405 U.S. 645 (1972).

123. Mueller, 576 F.3d at 984.

124. Id. at 983 .

125. Id. at 995 (quoting Wallis v. Spencer, 202 F.3d 1126, 1138 (9th Cir. 2000)) (noting, "[W]hen the State has 'reasonable cause to believe that the child is in imminent danger of serious bodily injury and ... the scope of the intrusion is reasonably necessary to avert that specific injury,' a State has the authority without prior judicial authorization to compel a minor child to undergo specific medical treatment over parental objections."). 
In Daniel's case, the court had time to weigh the situation and hear various testimonies, but in Taige's case, the vehicle used to wrest away custody was simply an empty determination that Taige was in imminent danger.

If the state is going to accept that a five percent risk of illness as enough to overrule a parent's decision regarding medical treatment for the child, ${ }^{126}$ then there is no point in even having an imminent danger exception. If so, then the state should immediately have the power to take away custody and decision making any time a parent and a physician disagree on treatment. The state has the burden of proving that interference in the child-parent relationship is necessary, ${ }^{127}$ and that was simply not accomplished in Mueller. This point further suggests that the Taige Mueller case was handled incorrectly. The counter-argument to this assessment is that the magnitude of harm to the child should also be considered. However, there is a point where the risk becomes so small that the magnitude of harm becomes inconsequential. For example, driving Taige to the hospital likely posed a risk of her becoming involved in a fatal car crash, but the risk was small enough that the decision was still left to Taige's mother.

On the other hand, supporters of the decision in Mueller would likely cite the urgency expressed by the physician. ${ }^{128}$ Because of the physician's pressure, the representatives of the state, who would ultimately decide what would happen in Taige's case, had no time to formally hear both sides of the story. If this was true, it only further highlights the difficulties bound to occur in these situations. Nevertheless, the removal of Taige Mueller from her mother and disregard of Corissa Mueller's wishes without any sort of formal hearing was incorrect.

The procedural analysis of this case suggests that Mueller may have been hastily and incorrectly decided. The state's interest in protecting the child could have been evaluated in terms of the risks and benefits of the spinal tap procedure had the physician not made the threat appear so immediate. ${ }^{129}$ This raises serious questions as to how similar circumstances would have fared under judicial scrutiny in a court hearing. Most likely the five percent chance of meningitis would have been weighed against the risk associated with the spinal tap proce-

126. See Santosky v. Kramer, 455 U.S. 745 (1982).

127. Newmark v. Williams, 588 A.2d 1108, 1110 (Del. 1991) (noting, "Although [the right to make important decisions for a child] is not absolute, the State has the burden of proving by clear and convincing evidence that intervening in the parent-child relationship is necessary to ensure the safety or health of the child.").

128. Mueller, 576 F.3d at 984.

129. Newmark, 588 A.2d at 1117 (stating, "[T] he linchpin in all cases discussing the 'best interests of a child', when a parent refuses to authorize medical care, is an evaluation of the risk of the procedure compared to its potential success."). 
dure. $^{130}$ Taige's parents were concerned enough about the risks from the procedure that they planned to not consent to the procedure beforehand. ${ }^{131}$ Had they been allowed to refuse, it is very likely that Taige's parents would have found a medical practitioner who agreed with their assessment, or at the very least respected their wishes. This would have solved the problem of judicial deferral to medical testimony, as contrary medical judgment would have been available. ${ }^{132}$

When viewed through the lens of the events surrounding Daniel Hauser, it seems clear that a procedural hearing was required for a fair outcome. The judge in the Hauser case made the right decision based on the evidence and found that the benefits of treating his cancer with chemotherapy outweighed the risks. Both sides were given an opportunity to be heard, and the judge decided that Daniel Hauser should be given the treatment that posed a high likelihood of saving his life. ${ }^{133}$ Had Taige Mueller been given a hearing to decide if a five percent chance of sickness outweighed her parent's vehement objections to the treatment, it is probable that Corissa Mueller never would have lost custody of her child.

\section{E. Did Neglect Mandate State Intervention?}

As stated above, decisions regarding a child's care are left to the parent. ${ }^{134}$ But, if the well-being of a child is at issue, the state may intervene to protect the child. ${ }^{135}$ The state's intervention may come from the doctrine of parens patriae. ${ }^{136}$

The concept of parens patriae can be seen unfolding during the events surrounding Daniel Hauser. Daniel's mother kidnapped him after the court ordered that he be treated using chemotherapy, and she fled the area with her son, forcing the court to act by authorizing police to find and detain Daniel. ${ }^{137}$ The court determined that Daniel should

130. See Custody of a Minor, 393 N.E.2d 836 (Mass. 1979).

131. Mueller, 576 F.3d at 983.

132. See In re D.G., 970 So.2d 486, 490 (Fla. Dist. Ct. App. 2007).

133. See Findings of Fact, Conclusions of Law, and Order, In re Hauser, No. JV-09068, 2009 WL 1421504 (Minn. Dist. Ct. May 14, 2009) (page numbers unavailable).

134. See Prince v. Massachusetts, 321 U.S. 158, 166 (1944).

135. Wisconsin v. Yoder, 406 U.S. 205, 233-34 (1972) (holding, "the power of the parent ... may be subject to limitation ... . if it appears that parental decisions will jeopardize the health or safety of the child ....").

136. See, e.g., In re D.G., 970 So.2d at 490 (noting, "parents' rights are not absolute, as the state has parens patriae authority to ensure that children receive reasonable medical treatment which is necessary for the preservation of life. And as between parent and child, the ultimate welfare of the child is the controlling factor.").

137. Order to Apprehend and Detain, In re Hauser, No. JV-09-068, at 5 (Minn. Dist. Ct. May 19, 2009), available at http://www.mncourts.gov/Documents/0/Public/Other/Hauser/ Order_to_Apprehend_and_Detain.pdf (ordering police to apprehend and detain Daniel Hauser). 
undergo chemotherapy, which his parents had purposefully chosen not to do, in hopes of pursuing alternative medicine. ${ }^{138}$ The removal of Daniel by his mother seemingly amounts to neglect on her part in the care of her child, and this appears to be the court's justification for eventually giving the Hauser family an ultimatum: accept the livesaving treatment or Daniel will be removed into state custody.

In Taige's case, there is seemingly little to justify the parens patriae doctrine, unless the state assumes that the spinal tap was necessary to preserve the life of the child. The physician's opinion was weighed by the officer in a pressure filled situation, not in a court with ample opportunity and weight given to each party. This suggests that even if there was enough evidence to invoke parens patriae, it is unlikely that the officer weighed, or was even capable of weighing, the parents' interests in this situation. The district court in Mueller stated that, "when an officer encounters an emergency situation where a parent is refusing medical treatment for her child, the officer's threshold task is to determine whether there is time and means to contact a judge." ${ }^{139}$ The court's opinion only further suggests that officers in this type of scenario are unfit to adequately balance the interests involved.

\section{F. Policy Arguments}

From a public policy perspective, Mueller and Hauser events serve as distinct examples of what is "right" with state intervention in a child's health care, and what is "wrong." The Hauser events show why the state must intervene. The state must not only protect its own interests in the well-being of the child, but also it must make sure that children like Daniel do not die because of their parent's decision. ${ }^{140}$ Instead, Daniel's case shows that when the state intervenes, children's lives can be saved, as Daniel's cancer seems to be in remission because of the state's interference. ${ }^{141}$

On the other hand, Mueller shows the pitfalls that can occur when the state is rushed into making a decision. Corissa Mueller had her child taken away from her, was forced to sit by while a procedure she feared and expressly rejected was performed on her daughter, and was not given any formal chance to have her opinions heard. ${ }^{142}$

138. See Judge Rules Family Can't Refuse Chemo, supra note 65.

139. Mueller ex rel. Mueller v. Auker, No. CV-04-399-S-BLW, 2007 WL 627620, *10 (D. Idaho Feb. 26, 2007).

140. See Prince v. Massachusetts, 321 U.S. 158, 170 (1944) (noting, "Parents may be free to become martyrs themselves. But it does not follow they are free, in identical circumstances, to make martyrs of their children before they have reached the age of full and legal discretion when they can make that choice for themselves.").

141. See Wasserman, supra note 43.

142. Mueller v. Auker, 576 F.3d 979, 983-86 (9th Cir. 2009). 


\section{Protecting the Child}

The events surrounding Daniel Hauser prove that state intervention can save lives in these scenarios. Without court intervention, Daniel would likely have died. Unfortunately, cases like this do occur and are timely in this discussion. ${ }^{143}$ As between any other concerns and the well-being of a sick child, the state should side with whatever option will best safeguard that child's health. ${ }^{144}$

For Daniel Hauser, the decision seems clear based on the outcome predicted by his physician. ${ }^{145}$ In cases like Daniel's, where the state has ample time to weigh the evidence for multiple courses of treatment, the state can safely decide what is best for the child. More difficult cases arise when scenarios like Taige Mueller's are presented where a decision must be made quickly.

In Taige's case, the state decided that a five percent risk warranted depriving a parent of the custody of her child and forcing unwanted medical treatment. ${ }^{146}$ However, based on the assessment of the risk, that decision should have required further inquiry. There are undoubtedly numerous dangers an infant will face as they mature, and it is likely that many of those risks will have a greater than five percent chance of occurring. However, unless the danger involves neglect, or in Taige's case a medical decision, it is unlikely that the state will ever be involved. To base such a difficult and emotional decision solely on a five percent chance of an event occurring cannot be the best possible solution. It is no surprise that the court in Mueller acknowledged that what happened was both difficult and undesired. ${ }^{147}$ In cases like Taige Mueller's, it is sound public policy that decisions that effectively strip away a parent's ability to care for his or her child be based upon more than a five percent risk.

There is also a policy argument against forcing unwanted health care when there may be potentially devastating side effects. ${ }^{148}$ Corissa Mueller was adamant that the spinal tap procedure had a chance of causing infection, paralysis, or brain damage. ${ }^{149}$ The risks of side ef-

143. Dirk Johnson, Trials for Parents Who Chose Faith Over Medicine, NY TIMES, Jan. 20, 2009, http://www.nytimes.com/2009/01/21/us/21 faith.html (discussing the story of a Wisconsin eleven-year-old girl who died because her parents believed that God alone could heal her illness, and did not seek out medical treatment).

144. In re D.G., 970 So.2d 486, 490 (Fla. Dist. Ct. App. 2007) ("And as between parent and child, the ultimate welfare of the child is the controlling factor.").

145. See Findings of Fact, Conclusions of Law, and Order, In re Hauser, No. JV-09068, 2009 WL 1421504 (Minn. Dist. Ct. May 14, 2009) (page numbers unavailable).

146. Mueller, 576 F.3d at $979,984$.

147. Id. at 1000.

148. Childhood Hodgkin Lymphoma Treatment, supra note 116.

149. Mueller ex rel. Mueller v. Auker, No. CV-04-399-S-BLW, 2007 WL 627620, *4

(D. Idaho Feb. 26, 2007) (referencing Corissa Mueller's deposition testimony). 
fects for medical treatment are usually something that is accepted in return for the possibility of the treatment being effective. However, when the treatment is unwanted, side effects become an independent risk that the state has decided the child must undertake. If either Taige or Daniel had experienced a severe side effect from their treatment, there would likely have been even more intense judicial scrutiny. It is important to acknowledge that when the state forces medical treatment with side effects on a child, there is always a potential that the unwanted treatment may actually do more harm than good.

\section{Parental Autonomy}

Whether or not Daniel's parents were justified in seeking alternative treatment, the fact that they were allowed to continue caring for him after his mother effectively kidnapped him shows they were considered fit parents. ${ }^{150}$ It is important to note that Daniel's parents seemed to disagree with the treatment, ${ }^{151}$ were likely fearful of the side effects, and had chosen an alternative form of treating Daniel's cancer.

When viewed from only a public policy perspective, the parental autonomy of a family should be held very high. Parents are given much leeway to raise their children, and it is in society's best interest that loving families be kept together. Parents maintain autonomy over selecting where their child will live, what they eat, when they go to bed, how much television they watch, nearly every aspect of their child's life, until that child becomes old enough to make decisions on their own. ${ }^{152}$

Nevertheless, the principle of parental autonomy is in direct contrast with what happened in the cases of Daniel Hauser and Taige Mueller. In most cases that do not involve neglect, it is in society's best interest to restrict the state's interference in the parent-child relationship. The courts have recognized this principle of restricting the state's interference. ${ }^{153}$ However, in cases that concern the child's safety, parental autonomy should be cast aside if the risk of refusing the medical care greatly outweighs the risk associated with the child being treated. In Daniel's case, the risk of refusing medical care was evident and was adamantly supported by the medical opinions of his physician. ${ }^{154}$ In a case like Daniel's, where a child's health is in serious

150. See Cooper \& Davis, supra note 10.

151. See Mother, Son Missing, supra note 34 (discussing letter from Daniel's parents stating that they "believe that the injection of chemotherapy into Danny Hauser amounts to an assault upon his body, and torture when it occurs over a long period of time.").

152. Prince v. Massachusetts, 321 U.S. 158, 166 (1944).

153. See Santosky v. Kramer, 455 U.S. 745 (1982).

154. See Findings of Fact, Conclusions of Law, and Order, In re Hauser, No. JV-09068, 2009 WL 1421504 (Minn. Dist. Ct. May 14, 2009) (page numbers unavailable). 
jeopardy and there is a clear discrepancy between the ramifications of the parent's decision and the effect prescribed treatment will likely have, the state should defer to the expertise of physicians if they are in the child's best interest. ${ }^{155}$

In a case such as Taige Mueller's however, the answer becomes less clear, and the analysis must adapt accordingly. A case like Taige's does not involve the same level of risk to the child when medical treatment is refused, and it is arguable that the risk to her well-being was minimal. ${ }^{156}$ In these scenarios, the opinions and wishes of the parents should be given weight when the state is evaluating whether or not medical treatment must be given to secure the well-being of the child. If society is to embrace the assumption that most parents will act in the best interests of their children, ${ }^{157}$ then the state must give weight to a parent's wishes when the risk to the well-being of the child is not significant.

\section{The Physician's Role}

The physicians in the Mueller and Hauser case had an intimate role in how these cases were resolved. Physicians are charged with caring for their patients. In Daniel's case, this meant recommending a form of treatment with known side effects. ${ }^{158}$ In Taige's case, this meant involving authorities who were forced to restrain a loving parent. From a policy perspective, we want physicians to care about their patient's well-being. It would be counterintuitive to hamper physicians in doing what they believe is best for their patients, especially when it comes to children who are, by law, incapable of giving medical consent. ${ }^{159}$ In both of these cases, the physicians believed the treatment they prescribed was in the child's best interest. Our society places immense trust in physicians, and this trust results from the years of training and education physicians must undergo before they are allowed to work as medically trained professionals.

As much research as Taige's mother had done on the issue of spinal taps on infants, it no doubt paled in comparison to the emergency room physician's knowledge of the subject. As a society, we do not want laymen making crucial life or death medical decisions. It is a

155. But see Newmark v. Williams, 588 A.2d 1108 (Del. 1991) (deciding that court would not order child with cancer to undergo radical form of treatment with a success rate of only forty percent).

155. See Prince, 321 U.S. at 166.

156. Mueller v. Auker, 576 F.3d 979 (9th Cir. 2009).

157. See generally Jacobs, supra note 47 at $\S 10: 3$.

158. Childhood Hodgkin Lymphoma Treatment, supra note 109.

159. See generally Jacobs, supra note 47 at $\S 10: 3$. 
physician's job to make informed medical decisions in high-pressure situations. This is precisely why expert medical testimony is generally given more weight compared to a parent's perspective on a course of treatment. $^{160}$

Finally, it is more likely that a physician will err on the side of caution when recommending a course of treatment. With the threat of malpractice suits, it is only natural for a physician to be overly cautious in most situations. Since medical testimony in these cases is heavily weighed, a physician may inadvertently affect the interests of the parent, simply by being safe in their recommended treatment. Again, we want physicians to do what is best for their patients, but unfortunately at times, this may mean interfering with a parent's right to care for her child without interference from the state. These decisions are difficult to make, especially in cases where time may be limited, and decisions need to be made quickly.

\section{State Actors Charged With Deciding What to Do in Difficult Situations}

The state social worker in Mueller had few options. ${ }^{161}$ A trained medical professional told her that a sick child needed a standard procedure, and that the window to do the procedure and treat the illness would close in less than three hours. ${ }^{162}$ From a policy perspective, any state actor placed in a similar situation does not have the ability to properly weigh the interests of the parent against the interests of the state in protecting the child. The state worker does not have the time or the legal or medical knowledge to properly assess the situation. This creates difficult scenarios like in Mueller where an official had to make a quick decision that they may not be adequately trained to make.

These cases also present difficult decisions for judges. The judge in Daniel Hauser's case issued a detainment order to force a child to undergo a treatment that had already made him sick, a treatment that his parents disagreed with. ${ }^{163}$ Likewise, if Taige Mueller had been given a hearing, a judge would have been forced to weigh the opinions of a concerned medical professional against the concerns of a loving and terrified mother. In reality, the time-sensitive nature of future cases that might resemble that of Taige Mueller are never going to provide enough time for a full hearing. This likely means that state actors will

160. See In re D.G., 970 So.2d 486 (Fla. Dist. Ct. App. 2007).

161. Mueller, 576 F.3d at 984 .

162. Id.

163. Order to Apprehend and Detain, In re Hauser, No. JV-09-068, at 5 (Minn. Dist. Ct. May 19, 2009), available at http://www.mncourts.gov/Documents/0/Public/Other/Hauser /Order_to_Apprehend_and_Detain.pdf. 
be forced to decide these extremely complicated issues with little time to consider all of the interests involved. ${ }^{164}$

\section{The State (Legislature)}

The state must maintain and protect its interest in the child. It cannot do this by bowing to every parent who does not agree with his or her physician's treatment plan. If the state sides with the parent and disregards the physician, the consequences can be dire. Thus, for a legislature to pose any sort of solution, it must be cognizant of the fact that certain parents will fail to choose the correct course of treatment for their sick child, possibly resulting in the child's death.

In Daniel's case, it is obvious that the state made the right decision and saved a child's life. On the other hand, in Mueller, the state deprived a well-informed family of the custody of their child and submitted the child to unwanted medical care.

\section{G. Possible Solution to a Complicated Problem}

The problems highlighted by Mueller and Daniel Hauser's case is that there are competing interests among the parties involved, and all parties believe they are making the best decision. The parents want to be able to care for their child free from interference, but the state must interfere if it believes the parents' decision creates enough risk to the child's life to require intervention.

Physicians and state actors such as police and social workers further complicate the problem. Both of these characters may be highly experienced in their particular fields, but they are unlikely to have the necessary understanding to adequately balance the legal interests at issue between parent and state. Practically though, they are the ones who ultimately make the decisions. Cases like Daniel Hauser's provide an adequate solution to the problem by bringing the dispute to the courtroom. In court, a judge can properly weigh the competing interests and come to a decision based on the particular factual scenario. This prevents state actors from making snap decisions that may infringe on the constitutional rights of parents.

When these types of cases are taken inside a courtroom, a judge can properly assess the risk of a child not having a treatment and weigh it

164. See generally Mathews v. Eldridge, 424 U.S. 319, (1976) (discussing the factors that will be weighed when determining whether a pre-deprivation, evidentiary hearing was needed. The court weighed the individual's interest at stake, the reliability of the current procedures in place and whether additional safeguards (like a trial) would have any effect, and the court weighed the costs and administrative burden that would arise from allowing such a hearing. In this case, the court found that no pre-deprivation hearing was required for the termination of social security benefits). 
against the parents' wishes and any dangers that may be associated with the treatment. If the risks of treatment are close to the risk of not treating in the recommended manner, the parents should be allowed to make the choice. ${ }^{165}$ If the risk of not treating outweighs the parents' interests and the danger of treatment, then the judge should order the treatment. ${ }^{166}$ Amidst this analysis, the judge can also weigh the side effects of the treatment on the child, the chance of successful treatment, and survival rate of the procedure.

Requiring more formal procedural due process works for multiple reasons. First, it allows the parents to actually be heard. Daniel Hauser's parents were given a hearing, and they were able to convey to the judge their own beliefs on how Daniel should be treated. ${ }^{167}$ The court was then given the opportunity to weigh those beliefs against the risks Daniel faced and, thus, was able to come to a properly reasoned conclusion.

Requiring a hearing also takes the burden off of the state. State actors are generally not equipped to make these kinds of decisions. They likely do not have the training or expertise to properly balance constitutional interests and medical risk. They also may lack the medical knowledge to make any sort of assessment involving the necessity of medical treatment. This highlights the greatest problem with the approach taken in Mueller. The person who made the ultimate decision as to whether the infant would receive a spinal tap against her parent's wishes had no medical expertise and was not capable of weighing the parent's interest. The state actor was simply caught in the middle of a dispute, trying to listen to complicated medical opinions and assess the wishes of an angry parent. This is not a job for a police officer or a CPS worker. It should instead fall to a trained judge whose day-to-day business is applying the principles according to the law and weighing the interests of opposing parties. Thus, the state actor's role in these scenarios will be greatly reduced, and they will come into the situation only after a judge has heard both sides and made a ruling.

A formal hearing also takes pressure off physicians. When physicians and parents disagree over a child's medical care, it creates a hostile situation and will likely lead to a lawsuit. ${ }^{168}$ By allowing physicians to make their case in a courtroom, it takes away the confrontational aspect of having to disagree with a parent while emotions are high. This also allows the parent of the child to seek a second medical opinion and have both sides of

165. Mueller ex rel. Mueller v. Auker, No. CV-04-399-S-BLW, 2007 WL 627620, *9 (D. Idaho Feb. 26, 2007) (noting, "[When] there is a close association between the risks of treatment and the risks of foregoing treatment ... [i] $t$ is now the grim duty of the parents to make the call.").

166. See Custody of a Minor, 393 N.E.2d 836 (Mass. 1979).

167. See Findings of Fact, Conclusions of Law, and Order, In re Hauser, No. JV-09068, 2009 WL 1421504 (Minn. Dist. Ct. May 14, 2009) (page numbers unavailable).

168. See, e.g., Mueller ex rel. Mueller, 2007 WL 627620, at *15-26 (Mueller's case with the parents suing not only the physician, but also nearly every other person and entity that was involved with making the decision to treat Taige.). 
medical testimony put in front of an impartial decision maker. Physicians may carry exponential weight in influencing treatment decisions; therefore, it is even more important that the medical testimony be carefully scrutinized.

There is also the fear that a physician might be exaggerating his diagnosis in an attempt to get the parents and state actors to consent to the treatment, which was alleged in Mueller. ${ }^{169}$ A hearing can allow physicians to explain their concerns about the treatment or procedure and can allow for differing opinions that may provide effective alternatives to be heard. The goal is that there is a chance for the parents to present their side of the story, as opposed to letting the physician's opinions completely control the situation.

Requiring a hearing before the state orders medical treatment for a child against a parent's wishes accomplishes multiple things: it allows parents to state their wishes for caring for the child; takes pressure off of state actors who otherwise could be forced to make a snap decision they are unqualified to make; and it lessens the chance of serious confrontation between physicians and parents. A hearing instead offers an effective outlet to voice opposing viewpoints with the potential for alternative medical approaches. A judge overseeing a hearing on this type of issue can weigh the evidence on each side and determine whether the parents should be left to care for their child, or if the state should step in and order the child to undergo treatment.

In addition, if physicians are aware of this process, they may be more likely to involve the court system when the decision to be made is a close one. This could, in turn, protect the well-being of children in cases where the physician deferred to the parent's wishes and should not have. It also means that parents will be given a chance to be heard, if their physician disagrees with them enough to involve the state.

One obvious criticism to this approach is implementing it in a timesensitive situation like Taige Mueller's. Taige's physician believed that a decision had to be made in three hours. ${ }^{170}$

This is a legitimate logistic-orientated concern. These concerns do arise in the real world, as evidenced by the detective in the Mueller scenario explaining that he chose not to involve a judge because he thought it would take too long to receive a response in the short time frame Taige's physician had laid out. ${ }^{171}$ This problem highlights a pragmatic roadblock, but the unique nature of these scenarios demand a proper solution. The deprivation of the ability to choose how to care for one's child is different from the loss of a property interest or infringement of a right, simply for the fact that it

169. Id.

170. Mueller v. Auker, 576 F.3d 979, 984 (9th Cir. 2009).

171. Mueller ex rel. Mueller, 2007 WL 627620, at *5. 
has the potential to end disastrously because of the nature of medical care, and how many things can go wrong in an emergency room. In situations like these, emotions may be running high between physician, parent, social worker, and officer, and the only way to resolve a proper outcome is to allow a neutral party, properly informed of the distinct interests at stake, hear the evidence and make a decision. If time is at issue, then it becomes even more important that access to this process be immediate, so as to avoid situations like Taige's, where an officer does not even bother to involve the court because he is worried about response time.

The best possible solution in these time-sensitive cases would be to have an informal hearing done by someone with expertise to make decisions, similar to an administrative law judge ("ALJ"). The crux of the solution will depend on the promptness and availability of the arbiter. When parent and physician disagree, the ALJ could conduct an informal hearingeven over the phone if need be, but, this hearing needs to be immediate. This entity would need to be directly linked to social services so that the agency could respond when physicians felt the need to involve the state.

The process would need to be informal because of possible time restraints. However, this does not mean that an informal reviewing entity could not take the time to properly weigh all the competing interests. The informal hearing would need to be conducted at the same time the state determines that there is not enough time for a formal hearing. The person in this position would need to be on call during set times, and capable of hearing disputes over medical care involving parents and physicians. As technology continues to progress, it seems likely that video conferencing could become a viable option for these individuals to hear relevant disputes, which will could allow for a more complete impromptu hearing.

Additional criticisms revolve around costs and resource availability. If a new system premised on immediacy is implemented, it will require constant staffing by those approved to properly weigh the issues and make a decision. The most logical candidates would be judges, but they are extremely limited in number, and it may be too far-fetched to expect judges to be available at all times in order to settle these issues if they should arise and require immediate attention.

Another option would be to train state social workers for these particular situations. This would require an intense focus on understanding the law, a commitment on top of ordinary job duties, and would need funding to come from somewhere. On top of increased costs, social workers are unlikely to ever have the same understanding of the legal interests at stake, when compared with judges.

An increase in costs is all but given should the solution focus on being able to react promptly, and this simply cannot be avoided. Costs could be somewhat deferred if the parents were asked to pay some of the costs, should they chose to invoke the system, much in the same way court fees are imposed when a person files suit. 
Preferably, judges would be the only arbiters of these decisions. The increased commitment would likely be tempered by the rarity of cases occurring that required immediate attention. Those that would arise are likely important enough decisions that society should desire a neutral decisionmaking outlet.

While implementing a new system focused on immediacy and availability of judges to hear these disputes is going to be difficult, there are two important policy implications to focus on. First, a case like that of Taige Mueller's must be given a proper forum in which to be heard. The legal rights of the parents involved and the possible consequences to the child's health are far too important to be made by ill-equipped state actors. Second, it is unlikely that cases as time sensitive as Taige Mueller's will occur frequently. Ultimately, society would rather have a judge at an impromptu hearing make this decision instead of a frazzled police officer or social worker listening only to the physician yelling in his ear.

A second important criticism involves the administrative burden this solution would create. Most courts already handle a heavy caseload, and this would only be increased by additional hearings of this type. The importance of these types of cases must not be overlooked simply because the courts are busy. A parent's right to care for her child is constitutionally protected. ${ }^{172}$ If this right is to be taken away, the parent must have a chance to be heard. If the only way to give parents a chance to be heard when the life of their child is at stake is to appoint special judicial positions to hear these cases, then the legislature should be relied upon to do just that.

\section{CONCLUSION}

The interests at stake when considering unwanted medical treatment for children are extremely important. As was discussed in the case of Daniel Hauser, an incorrect decision on the part of a state actor could be fatal to a child whose parents choose not to follow the physician's orders. In those cases, the state is justified in stepping in, despite the wishes of the parents. When the welfare of the child is at a severe risk without medical care, the state must become involved.

On the other hand, there is a significant interest that parents have in raising and caring for their children without unwanted interference from the state. In Mueller, the state made a rushed decision that deprived Corissa Mueller of her daughter, and forced her to sit by and wait for her child to undergo a medical procedure she had refused. In that case, the state should have weighed other factors. In cases like these, where the risk to the child's well-being is small, other concerns should come into play before the state forces a child to undergo treat- 
ment.

These situations should not be decided based on yelling matches between physicians and parents. If a system were put in place where judges could immediately be contacted, parents would be given a chance to be heard before medical care was forced upon their child. If evidence was presented in each scenario from both sides under a uniform federal standard, parents would at least be given some say in the child's medical care when they disagree with the child's physicians. In the end, the judge could make a rational decision based on the parent's role and the physician's concern over treatment. Even if the decision needs to be made immediately, a judge hearing both sides in an impromptu telephone conference is a better option than asking a police officer to make a rash decision.

The criticisms to this approach would focus on the costs and administrative burdens on a court system that is already stretched thin. While this is a real concern, it should not be enough to deter a state from implementing a process that would adequately protect both its interests and those of the parent. Ultimately, this solution gives parents a chance to be heard. This process will allow an experienced judge, to weigh the evidence and make a better decision then a police officer or untrained social worker is capable of. 